\title{
Analysis of Iron, Scandium, Samarium, and Zinc in Commercial Fertilizers and the Chemistry behind the Stability of These Metals in the Fertilizers
}

\author{
Md Sajjadur Rahman', Syed Mohammod Hossain ${ }^{2}$, Mir Tamzid Rahman ${ }^{3 *}$, Mahbub Kabir ${ }^{3}$ \\ ${ }^{1}$ Department of Chemistry and Biochemistry, South Dakota State University, Brookings, SD, USA \\ ${ }^{2}$ Reactor and Neutron Physics Division, INST, Atomic Energy Research Establishment, Dhaka, Bangladesh \\ ${ }^{3}$ Department of Chemistry, Jahangirnagar University, Dhaka, Bangladesh \\ Email: ^tamzidjuchem@gmail.com
}

How to cite this paper: Rahman, Md.S., Hossain, S.M., Rahman, M.T. and Kabir, M. (2019) Analysis of Iron, Scandium, Samarium, and Zinc in Commercial Fertilizers and the Chemistry behind the Stability of These Metals in the Fertilizers. Journal of Agricultural Chemistry and Environment, 8, 155-171.

https://doi.org/10.4236/jacen.2019.83013

Received: July 1, 2019

Accepted: August 13, 2019

Published: August 16, 2019

Copyright $\odot 2019$ by author(s) and Scientific Research Publishing Inc. This work is licensed under the Creative Commons Attribution International License (CC BY 4.0).

http://creativecommons.org/licenses/by/4.0/

\begin{abstract}
Fertilizers are the indispensable materials for farming and one of the major components of the current world economy. It is essential to understand the chemical structures of fertilizers to provide best quality products to the consumers. In this study, chemical structures of some frequently used commercial fertilizers (compost, DAP, and TSP) and their phosphate-metal interaction chemistry were studied employing both analytical and theoretical methods. Three types of fertilizer samples from the mid-southern part of Bangladesh were collected to quantify the content of two micronutrient metals (iron and zinc) and two non-essential metals (scandium and samarium). Neutron activation analysis (NAA) coupled with $\gamma$-ray spectrometry was employed to analyze the content of the metals where three standard reference materials, namely IAEA-SL-1 (Lake Sediment), IAEA-Soil-7, and NIST Coal Fly Ash 1633b, were used. Concentration of Fe $(2964-24,485) \mathrm{mg} / \mathrm{kg}$, Sc (3.50 - 11.80) mg/kg, Sm (2.19 - 26.69) mg/kg, and Zn (243 - 4426) mg/kg were determined in the fertilizer samples. Extremely high concentrations of $\mathrm{Fe}$ and $\mathrm{Zn}$ were quantified in some of the compost and phosphate fertilizers in comparison with other studies of different countries. Quantum mechanical calculations were performed to understand the molecular level interactions of $\mathrm{Fe}$ and $\mathrm{Zn}$ with triple super phosphate (TSP) and diammonium phosphate (DAP) fertilizers by employing DFT-B3LYP/SDD level theory. Results showed that both $\mathrm{Fe}$ and $\mathrm{Zn}$ have high affinity with the phosphate fertilizers, but Fe compound showed stronger binding affinity than the $\mathrm{Zn}$ compounds, which supported the experimental results. Another interesting finding was
\end{abstract}


that the compounds of $\mathrm{Fe}$ and $\mathrm{Zn}$ attached to the oxygen of the phosphate group of the fertilizers by covalent-like bonding. HOMO-LUMO gaps of the Fe-DAP/TSP complexes were observed significantly lower than the $\mathrm{Zn}$-DAP/TSP, which also demonstrated that Fe compound could have higher affinity to attach with the phosphate group of DAP and TSP fertilizers.

\section{Keywords}

Phosphate Fertilizer, NAA, $\gamma$-Ray Spectrometry, Metal-Phosphate Interaction, DFT

\section{Introduction}

Fertilizers are indispensable materials, providing essential nutrients to soil to maximize food production. Fertilizers are becoming one of the essential factors of the world economy [1]. So, it is easily comprehensible that the need for fertilizer is increasing tremendously. World demand for phosphate fertilizers was $41,700,000$ tons in 2013, but it is expected to become 46,600,000 tons by 2018 [1]. Among the phosphate fertilizers, DAP and TSP are the most consumed fertilizers [2], because both can supply high content of phosphorous, where DAP can also provide high amount of nitrogen [3]. Manufacturers sometimes mix high amounts of phosphate ores and recycled by-products to the fertilizers to meet the nutritional needs of soil [4] [5]. In this way, excessive amount of trace metals could be ingested into the fertilizers. The common forms of those metals in the fertilizers are oxides and sulphates [6] [7]. Since some of these metallic compounds show great affinity to the phosphate groups, after the application of the phosphate fertilizers, those compounds could retain in the topsoil for a longer period of time [8]. Moreover, metals could also stay in soil and water for an extended period of time by changing their oxidation state and worsening the soil environment [9]. Every stakeholder should maintain the quality of the fertilizers, starting from manufacturing process to packaging and must state quality control results on their packages according to the suggestion and trend reported by international regulatory bodies such as FAO, USGS, or USDA [1] [10] [11] [12]. In this study, excessive amount of micronutrient metals, e.g. Fe and Zn detected in some of the fertilizer samples. Therefore, this study tried to find out the reasons behind the high concentration of the metals in the phosphate fertilizer samples by employing density functional theory calculations.

It is important to know because excessive exposure of the essential nutrient metals could cause severe environmental and health hazards. Elevated level of $\mathrm{Fe}$ can cause "Bronzing" of the rice leaves, which reduces the rice-yield; it can even cause complete crop failure [13]. Zinc is also an essential trace element since it has the antagonistic capacity against copper and cadmium toxicity [14] [15], but application of large doses of zinc over extended periods of time by diverse sources such as fertilizers, pesticides, and manure could cause $\mathrm{Zn}$ induced iron 
deficiency-chlorosis. When plant leaves exceed $500 \mathrm{mg} \mathrm{Zn/kg} \mathrm{DW} \mathrm{then} \mathrm{it} \mathrm{could}$ cause phytotoxicity [16].

Scandium and samarium metals do not get absorbed by the plants to a measurable extent, so these metals should not have any significant role in agricultural soil and the human diet, but Rim et al. [17] reported that samarium could be slightly toxic in its soluble form.

Quantification of metal contents in diversified types of samples can be accomplished by various methods such as Inductively Coupled Plasma-Atomic Emission Spectrometry (ICPAES) [18], Continuum Source Graphite Furnace Atomic Absorption Spectrophotometry (CS-GFAAS) [19], Wavelength Dispersive X-Ray Fluorescence Spectrometry (WD-XRF) [20], Proton-Induced X-ray Emission (PIXE) [21], and Neutron Activation Analysis (NAA) [8]. Each method has its own advantages and disadvantages, but NAA method was used in this study because it needs no chemical treatment, non-destructive, matrix independent only based on the $(\mathrm{n}, \gamma)$ nuclear reaction, and IAEA regarded it as a "Reference Method" [22]. The only difficulty to run this method could be its overall cost.

Density functional theory (DFT) is one of the most effective ways to study different chemical, material, and biological system [23]. To comprehensively understand the structural changes, binding energy changes, and other modifications occurred by strong interaction of metallic compounds with fertilizers, DFT calculations can play a successful role [8].

In this study, we investigated $\mathrm{Fe}, \mathrm{Sc}, \mathrm{Sm}$, and $\mathrm{Zn}$ contents in frequently used commercial fertilizers from the mid-southern region of Bangladesh employed by neutron activation analysis (NAA). In addition, quantum mechanical calculations revealed the structural characteristics of the fertilizers, TSP and DAP, and the compounds interacting with them. The structural changes occurred in fertilizers due to the interaction of Fe and $\mathrm{Zn}$ compounds, and the reasons behind the compounds high affinity to the fertilizers were explored.

\section{Materials and Methods}

\subsection{Sample Collection}

The detail method of sample collection was explained in our earlier study [8]. Concisely, total ten phosphate (TSP and DAP) and compost fertilizer samples were collected to observe the level of essential (Fe and $\mathrm{Zn}$ ) and non-essential metals (Sc and Sm) from the mid-southern part of Bangladesh namely; Alfadanga and Shaltha in Faridpur, Agargaon, Mirpur-2 (Kingshook Nursery), Savar (Gerua Bazar) in Dhaka, and Mohammadpur in Magura [8]. Sample identification numbers were assigned as, C11-L, C13L, C14-L, T22-L, T32-L, T42-L, T52-L, T62-L, D24-L, and D54-L where C, T, and D means compost, TSP, and DAP, respectively. Coordination data of the sample collection points are presented in Table S1.

\subsection{Sample Preparation for INAA Analysis}

Sample preparation and correction of the interference were also described in the 
previous study [8]. In brief, collected samples were taken into an electric oven to dry about $65^{\circ} \mathrm{C}$ until having constant weight. About $60 \mathrm{mg}$ of dried, homogeneous, and powdered fertilizer samples were heat sealed in a small polyethylene bag. Three standard reference materials (SRMs) were used where IAEA-Soil-7 was used as a standard, and IAEA-SL-1, NIST-1633b (Coal Fly Ash) were used as the control samples. Three $0.1 \mathrm{~mm}$ thick $\mathrm{Al}-\mathrm{Au}$ foil monitor foils were placed within the sample pile and irradiated those along with the samples to determine the neutron flux gradient. Three megawatt (MW) TRIGA Mark-II research reactor was used in this nondestructive relative standardization approach. Long irradiation of reference materials and samples in the rotary specimen rack applying $5.07 \times 10^{13} \mathrm{ncm}^{-2} \cdot \mathrm{sec}^{-1}$ thermal neutron flux for 6 minutes at $2.4 \mathrm{MW}$ was conducted. A pre-calibrated HPGe detector [CANBERRA, $25 \%$ efficiency relative to a $\mathrm{NaI}(\mathrm{Tl})$ detector, $1.8 \mathrm{keV}$ resolution at $1332.5 \mathrm{keV}$ of ${ }^{60} \mathrm{Co}$ ] connected to a digital gamma spectrometer (ORTEC, DSPEC Jr${ }^{\mathrm{TM}}$ ) was used. The $\gamma$-rays emitted from both the samples and standards were measured at the same geometry. The dead time of the detector was kept below $15 \%$.

Two steps of counting were performed for the long irradiation. The first counting was performed to determine Sm content in samples, standard, and controls after a decay time of 1 day, with the lifetime of 1800 - $3000 \mathrm{~s}$ with the acquisition software Maestro-32 (ORTEC). The second counting was conducted after 3 weeks with the lifetime of $7200 \mathrm{~s}$ for the determination of Fe, Sc, and $\mathrm{Zn}$.

\subsection{Quality Control and Detection Limit}

Ratio of the measured concentrations of the studied metals in control samples (NIST-1633b Coal Fly Ash and IAEA-SL-1) to their certified concentrations gave a strong quality control result for this experiment (Figure S1(a) and Figure S1(b)). Deviations were found within $5 \%$ for most of the metals in both cases except Sm in SL-1 had 12\% deviation, and the deviation calculated for $\mathrm{Zn}$ in NIST 1633 b was $28 \%$. Overall, the QC results provided reliability of the calculated results. A three- $\sigma$ criterion [8] was employed to calculate the detection limit of studied metals (Table S2).

\subsection{Computational Method}

Gaussian 09 software package [24] was used to optimize the structures of DAP and TSP and their complexes with $\mathrm{FeSO}_{4}, \mathrm{ZnO}$, and $\mathrm{ZnSO}_{4}$ at gas phase. Vibrational frequencies were calculated with the density functional theory (DFT) employing (BLYP) correlation functional [25]. All calculations were conducted by SDD basis set, which can produce reliable results for the interaction between metallic compounds and phosphate fertilizers [8] [26]. After computing, several thermochemical properties such as change of electronic energies, enthalpies, Gibbs free energies, HOMO-LUMO gaps, dipole moments, hardness and softness of the fertilizers, and the fertilizer-metal complexes were investigated. 


\section{Results and Discussion}

\subsection{Iron and Zinc Content in Compost, TSP, and DAP}

The concentrations of iron in compost, TSP, and DAP are 13,206.783 24,484.775 mg/kg, 2963.809 - 19,615.839 mg/kg, and 18,398.228 - 23,403.794 $\mathrm{mg} / \mathrm{kg}$, respectively (Figure $1(\mathrm{a})$ ). All compost samples contain the concentration of iron are $(\mathrm{C} 11-\mathrm{L}=13,512.279 \pm 457.814 \mathrm{mg} / \mathrm{kg} ; \mathrm{C} 13 \mathrm{~L}=24,484.775 \pm$ $740.027 \mathrm{mg} / \mathrm{kg}, \mathrm{C} 14-\mathrm{L}=13,206.783 \pm 462.619 \mathrm{mg} / \mathrm{kg}) ;$ TSP samples $(\mathrm{T} 22-\mathrm{L}=$ $3806.085 \pm 202.853 \mathrm{mg} / \mathrm{kg}, \mathrm{T} 32-\mathrm{L}=3435.955 \pm 193.816 \mathrm{mg} / \mathrm{kg}, \mathrm{T} 42-\mathrm{L}=$ $19615.839 \pm 623.845 \mathrm{mg} / \mathrm{kg}, \mathrm{T} 52-\mathrm{L}=4147.968 \pm 212.192 \mathrm{mg} / \mathrm{kg}, \mathrm{T} 62-\mathrm{L}=$ $2963.809 \pm 176.921 \mathrm{mg} / \mathrm{kg})$; and DAP samples $(\mathrm{D} 24-\mathrm{L}=18,398.228 \pm 598.977$ $\mathrm{mg} / \mathrm{kg}, \mathrm{D} 54-\mathrm{L}=23,403.794 \pm 695.150 \mathrm{mg} / \mathrm{kg})$. Concentration of Fe in DAP and compost seems remarkably higher than the other studies such as Chile and Egypt (Table 1). The ranges of iron concentration in soil samples of Punjab (India) reported $2800.0-5700.0 \mathrm{mg} / \mathrm{kg}$ (Table S3). Therefore, the repeated use of extremely high iron-enriched fertilizers could be turned into beneficiary evil.

Table 1. Ranges and mean concentration of Fe (mg/kg), Sc (mg/kg), Sm (mg/kg), and Zn (mg/kg) in phosphate fertilizers of different countries.

\begin{tabular}{|c|c|c|c|c|c|c|c|}
\hline $\begin{array}{l}\text { Region/ } \\
\text { Country }\end{array}$ & $\begin{array}{l}\text { Number of } \\
\text { Samples }\end{array}$ & Types & $\begin{array}{c}\text { Ranges } \\
\mathrm{Fe}(\mathrm{mg} / \mathrm{kg})\end{array}$ & $\begin{array}{c}\text { Mean } \\
\mathrm{Fe}(\mathrm{mg} / \mathrm{kg})\end{array}$ & $\begin{array}{c}\text { Ranges } \\
\mathrm{Zn}(\mathrm{mg} / \mathrm{kg})\end{array}$ & $\begin{array}{c}\text { Mean } \\
\mathrm{Zn}(\mathrm{mg} / \mathrm{kg})\end{array}$ & $\begin{array}{l}\text { Refer- } \\
\text { ences }\end{array}$ \\
\hline \multirow[t]{2}{*}{ Chile } & 12 & TSP & $5200.0-6800.0$ & 6000.0 & $43.0-883.0$ & 600.0 & \multirow{2}{*}{ [29] } \\
\hline & & DAP & $7100.0-11,000.0$ & 9100.0 & $38.1-44.5$ & 41.3 & \\
\hline Egypt & - & Superphosphate & & 7600.0 & & 107.80 & [28] \\
\hline \multirow[t]{2}{*}{$\begin{array}{l}\text { Europe (12 } \\
\text { Countries) }\end{array}$} & 196 & Phosphate & - & - & - & 166.0 & [27] \\
\hline & & TSP & $2963.81-19,615.84$ & 6793.93 & $243.33-472.52$ & 346.73 & \multirow{5}{*}{$\begin{array}{l}\text { This } \\
\text { study }\end{array}$} \\
\hline \multirow[t]{4}{*}{ Bangladesh } & \multirow[t]{4}{*}{10} & DAP & $18,398.23-23,403.79$ & $20,901.01$ & $348.14-4426.17$ & 2387.15 & \\
\hline & & \multirow[t]{3}{*}{ Compost } & $13,206.78-24,484.78$ & $17,067.95$ & $312.73-3359.90$ & 1511.22 & \\
\hline & & & Ranges & Mean & Ranges & Mean & \\
\hline & & & $\mathrm{Sc}(\mathrm{mg} / \mathrm{kg})$ & $\mathrm{Sc}(\mathrm{mg} / \mathrm{kg})$ & $\mathrm{Sm}(\mathrm{mg} / \mathrm{kg})$ & $\mathrm{Sm}(\mathrm{mg} / \mathrm{kg})$ & \\
\hline \multirow[t]{2}{*}{ Pakistan } & \multirow[t]{2}{*}{-} & SSP & - & - & - & 2.02 & \multirow{2}{*}{ [41] } \\
\hline & & DAP & - & - & - & 12.0 & \\
\hline Brazil & - & SSP & & 24.6 & & 122.0 & {$[36]$} \\
\hline \multirow[t]{2}{*}{ Brazil } & - & MAP & & - & & 43.0 & \multirow{2}{*}{ [41] } \\
\hline & & TSP & & - & & 89.0 & \\
\hline Egypt & - & Superphosphate & - & 3.99 & - & - & [28] \\
\hline \multirow[t]{3}{*}{ Bangladesh } & & TSP & $5.74-11.80$ & 7.92 & $6.38-26.69$ & 14.807 & \multirow{3}{*}{$\begin{array}{l}\text { This } \\
\text { study }\end{array}$} \\
\hline & 10 & DAP & $6.97-8.42$ & 7.694 & $6.58-7.22$ & 6.902 & \\
\hline & & Compost & $3.50-7.09$ & 4.785 & $2.19-3.88$ & 3.075 & \\
\hline
\end{tabular}


The concentration ranges of zinc in compost, TSP, and DAP fertilizers are $312.734-3359.896 \mathrm{mg} / \mathrm{kg}, 243.327-472.515 \mathrm{mg} / \mathrm{kg}$, and $348.135-4426.172$ $\mathrm{mg} / \mathrm{kg}$, respectively (Figure $1(\mathrm{~d})$ ). All compost samples $(\mathrm{C} 11-\mathrm{L}=3359.896 \pm$ $193.670 \mathrm{mg} / \mathrm{kg}, \mathrm{C} 13-\mathrm{L}=861.017 \pm 46.716 \mathrm{mg} / \mathrm{kg}$ and $\mathrm{C} 14-\mathrm{L}=312.734 \pm 19.156$ $\mathrm{mg} / \mathrm{kg}) ; \mathrm{TSP}$ samples $(\mathrm{T} 22-\mathrm{L}=262.236 \pm 16.421 \mathrm{mg} / \mathrm{kg}, \mathrm{T} 32-\mathrm{L}=243.327 \pm$ $17.541 \mathrm{mg} / \mathrm{kg}, \mathrm{T} 42-\mathrm{L}=398.272 \pm 26.452 \mathrm{mg} / \mathrm{kg}, \mathrm{T} 52-\mathrm{L}=357.313 \pm 24.710$ $\mathrm{mg} / \mathrm{kg}$, T62-L $=472.515 \pm 31.520 \mathrm{mg} / \mathrm{kg}) ;$ and DAP samples $(\mathrm{D} 24-\mathrm{L}=348.135 \pm$ $23.588 \mathrm{mg} / \mathrm{kg}, \mathrm{D} 54-\mathrm{L}=4426.172 \pm 259.968 \mathrm{mg} / \mathrm{kg}$ ) contain $\mathrm{Zn}$ in extremely high concentration compared to the European and Egypt market, specially C11-L, C13-L, T52-L, and D54-L.

The average $\mathrm{Zn}$ concentration in the phosphate fertilizers in European market was reported $166 \mathrm{mg} / \mathrm{kg}$ [27] where average $\mathrm{Zn}$ content in superphosphate fertilizer of Egypt market was $107.80 \mathrm{mg} / \mathrm{kg}$ [28] and $\mathrm{Zn}$ content in phosphate fertilizers of Chile market was 41.3 to $600.0 \mathrm{mg} / \mathrm{kg}$ [29]. So, the concentrations of $\mathrm{Zn}$ in sample C11-L and D54-L were found about 20 times and 27 times higher than the European market, respectively.

Zinc is unevenly distributed in soil and its concentration ranges between 73.0 to $320.0 \mathrm{mg} / \mathrm{kg}$ in Punjab (India) [30]. Kabata-Pendias and Pendias [31] stated that calcareous soils and organic soils can contain the highest background $\mathrm{Zn}$ contents. Moreover, several studies of USA and European countries reported that average concentration of $\mathrm{Zn}$ in soil can vary between $<3$ and $264 \mathrm{mg} / \mathrm{kg}$ in Table S3 [31] [32] [33] [34]. Besides concentration of $\mathrm{Zn}$ found in agricultural soils of Japan is 2.5 to $330 \mathrm{mg} / \mathrm{kg}$ [35]. On that account, some of the fertilizer samples contain extremely high amounts of $\mathrm{Zn}$.

\subsection{Scandium and Samarium Content in Compost, TSP, and DAP}

The concentrations of scandium in compost, TSP, and DAP are 3.496- 7.092 $\mathrm{mg} / \mathrm{kg}, 5.735-11.796 \mathrm{mg} / \mathrm{kg}$, and $6.965-8.423 \mathrm{mg} / \mathrm{kg}$, respectively (Figure $1(\mathrm{~b})$ ). All compost samples contain the concentration of scandium are $(\mathrm{C} 11-\mathrm{L}=3.767 \pm$ $0.248 \mathrm{mg} / \mathrm{kg}, \mathrm{C} 13-\mathrm{L}=7.092 \pm 0.461 \mathrm{mg} / \mathrm{kg}$ and $\mathrm{C} 14-\mathrm{L}=3.496 \pm 0.230 \mathrm{mg} / \mathrm{kg}) ;$
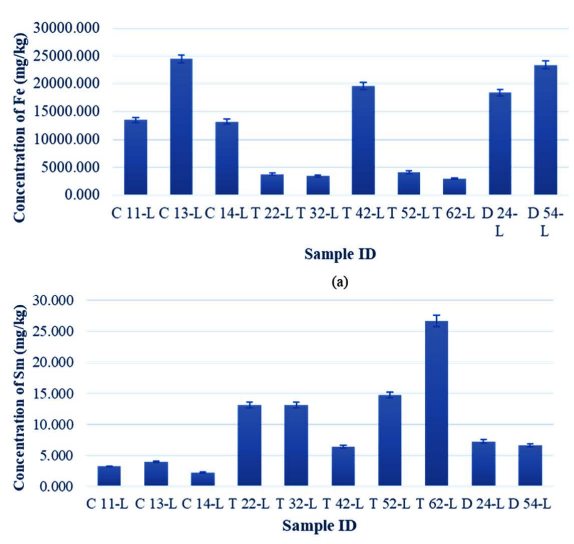

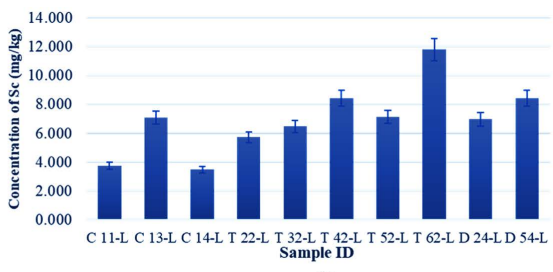

(b)

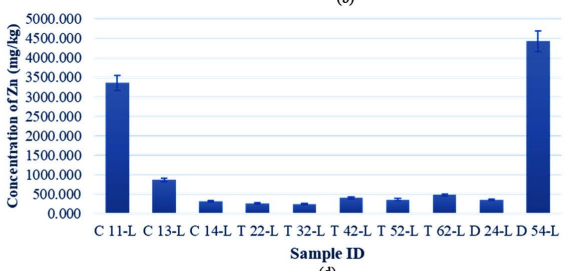

Figure 1. Concentration of (a) Fe (iron), (b) Sc (scandium) (c) Sm (samarium), and (d) $\mathrm{Zn}$ (zinc) in studied samples where $\mathrm{C}=$ Compost, $\mathrm{T}=\mathrm{TSP}$, and $\mathrm{D}=\mathrm{DAP}$. 
TSP samples $(\mathrm{T} 22-\mathrm{L}=5.735 \pm 0.374 \mathrm{mg} / \mathrm{kg}, \mathrm{T} 32-\mathrm{L}=6.478 \pm 0.422 \mathrm{mg} / \mathrm{kg}$, $\mathrm{T} 42-\mathrm{L}=8.432 \pm 0.548 \mathrm{mg} / \mathrm{kg}, \mathrm{T} 52-\mathrm{L}=7.139 \pm 0.465 \mathrm{mg} / \mathrm{kg}, \mathrm{T} 62-\mathrm{L}=11.796 \pm$ $0.764 \mathrm{mg} / \mathrm{kg}$ ); and DAP samples (D24-L = $6.965 \pm 0.454 \mathrm{mg} / \mathrm{kg}, \mathrm{D} 54-\mathrm{L}=8.423 \pm$ $0.547 \mathrm{mg} / \mathrm{kg}$ ). Turra et al., 2011 reported the mean concentration of Sc in SSP fertilizers of Brazil is $24.6 \mathrm{mg} / \mathrm{kg}$. Besides, the range of the mean concentrations of Sc in the soil reported in the studies of countries across the world is 6.1 to 18.0 $\mathrm{mg} / \mathrm{kg}$ [36] [37] [38] [39] [40] (Table S3). These results showed that estimated Sm contents in the fertilizer samples are within normal limit.

Additionally, the ranges of Sm concentration in compost, TSP and DAP were measured as $2.186-3.879 \mathrm{mg} / \mathrm{kg}, 6.381-26.694 \mathrm{mg} / \mathrm{kg}$, and $6.581-7.223 \mathrm{mg} / \mathrm{kg}$, respectively. Average concentration of $\mathrm{Sm}$ in the studied fertilizer samples are less than most of the studies reported in Table 1 except Pakistan [28] [36] [41] [42]. All compost samples (C11-L = 3.161 $\pm 0.109 \mathrm{mg} / \mathrm{kg}, \mathrm{C} 13-\mathrm{L}=3.879 \pm 0.134$ $\mathrm{mg} / \mathrm{kg}$ and $\mathrm{C} 14-\mathrm{L}=2.186 \pm 0.076 \mathrm{mg} / \mathrm{kg}) ; \mathrm{TSP}$ samples $(\mathrm{T} 22-\mathrm{L}=13.138 \pm 0.453$ $\mathrm{mg} / \mathrm{kg}, \mathrm{T} 32-\mathrm{L}=13.121 \pm 0.452 \mathrm{mg} / \mathrm{kg}, \mathrm{T} 42-\mathrm{L}=6.381 \pm 0.220 \mathrm{mg} / \mathrm{kg}, \mathrm{T} 52-\mathrm{L}=$ $14.703 \pm 0.507 \mathrm{mg} / \mathrm{kg}, \mathrm{T} 62-\mathrm{L}=26.694 \pm 0.921 \mathrm{mg} / \mathrm{kg}$ ); and DAP samples $(\mathrm{D} 24-\mathrm{L}=7.223 \pm 0.249 \mathrm{mg} / \mathrm{kg}, \mathrm{D} 54-\mathrm{L}=6.581 \pm 0.227 \mathrm{mg} / \mathrm{kg})$ contain Sm within the expected limit compared to the other studies.

\subsection{Interaction and Binding of Fe and $\mathrm{Zn}$ with TSP}

Equilibrium geometry and the optimized structures of TSP and its complexes TSP-FeSO ${ }_{4}, \mathrm{TSP}-\mathrm{ZnO}$, and TSP- $\mathrm{ZnSO}_{4}$ are presented in Figure 2. Chosen bond distances and angles of the complexes are summarized in Table 2 (atom numbers are indicated in the optimized structures). Few significant changes were occurred compared in the structure of TSP when it forms complex with $\mathrm{ZnO}$. In ZnO-TSP, $\mathrm{Ca}(15)-\mathrm{O}(10)$ elongated from $2.32 \AA$ to $4.17 \AA$. To compare the structural changes in $\mathrm{TSP}-\mathrm{FeSO}_{4}$ and TSP- $\mathrm{ZnSO}_{4}$, bond distances between $\mathrm{Fe}$

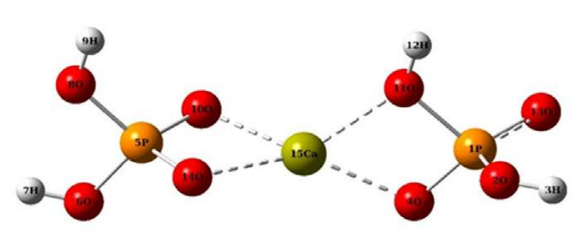

(a)

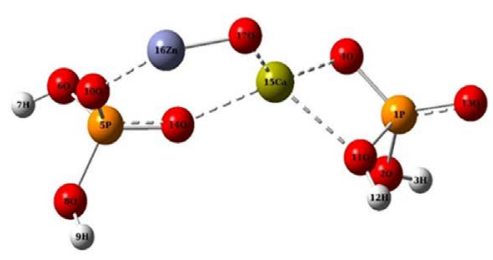

(c)

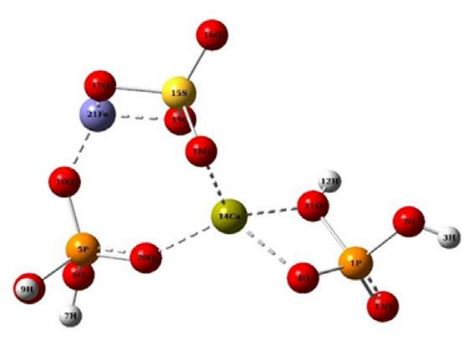

(b)

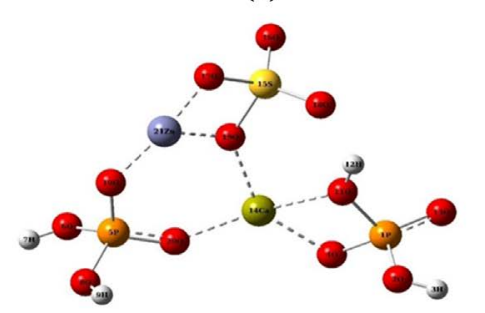

(d)

Figure 2. Optimized structures of (a) TSP; (b) TSP-FeSO ; (c) TSP-ZnO; and (d) TSP- $\mathrm{ZnSO}_{4}$ computed at B3LYP/SDD level of theory. 
Md. S. Rahman et al.

Table 2. Selected bond distances $(\AA)$ and angles $\left({ }^{\circ}\right)$ of TSP-metal complexes calculated at B3LYP/SDD level of theory.

\begin{tabular}{|c|c|c|c|c|c|c|c|}
\hline Assignment & TSP & Assignment & $\mathrm{TSP}_{-} \mathrm{FeSO}_{4}$ & Assignment & TSP-ZnO & Assignment & $\mathrm{TSP}_{-} \mathrm{ZnSO}{ }_{4}$ \\
\hline $\mathrm{Ca}(15)-\mathrm{O}(4)$ & 2.22 & $\mathrm{Ca}(14)-\mathrm{O}(4)$ & 2.22 & $\mathrm{Ca}(15)-\mathrm{O}(4)$ & 2.25 & $\mathrm{Ca}(14)-\mathrm{O}(4)$ & 2.21 \\
\hline $\mathrm{Ca}(15)-\mathrm{O}(10)$ & 2.32 & $\mathrm{Ca}(14)-\mathrm{O}(10)$ & 4.08 & $\mathrm{Ca}(15)-\mathrm{O}(10)$ & 4.17 & $\mathrm{Ca}(14)-\mathrm{O}(10)$ & 4.20 \\
\hline $\mathrm{Ca}(15)-\mathrm{O}(11)$ & 2.34 & $\mathrm{Ca}(14)-\mathrm{O}(11)$ & 2.35 & $\mathrm{Ca}(15)-\mathrm{O}(11)$ & 2.37 & $\mathrm{Ca}(14)-\mathrm{O}(11)$ & 2.30 \\
\hline $\mathrm{Ca}(15)-\mathrm{O}(14)$ & 2.32 & $\mathrm{Ca}(14)-\mathrm{O}(18)$ & 2.39 & $\mathrm{Ca}(15)-\mathrm{O}(14)$ & 2.30 & $\mathrm{Ca}(14)-\mathrm{O}(19)$ & 2.27 \\
\hline $\mathrm{P}(5)-\mathrm{O}(10)$ & 1.63 & $\mathrm{P}(5)-\mathrm{O}(10)$ & 1.63 & $\mathrm{P}(5)-\mathrm{O}(10)$ & 1.65 & $\mathrm{P}(5)-\mathrm{O}(10)$ & 1.64 \\
\hline $\mathrm{P}(5)-\mathrm{O}(8)$ & 1.70 & $\mathrm{P}(5)-\mathrm{O}(8)$ & 1.68 & $\mathrm{P}(5)-\mathrm{O}(8)$ & 1.68 & $\mathrm{P}(5)-\mathrm{O}(8)$ & 1.68 \\
\hline $\mathrm{P}(5)-\mathrm{O}(6)$ & 1.68 & $\mathrm{P}(5)-\mathrm{O}(6)$ & 1.66 & $\mathrm{P}(5)-\mathrm{O}(6)$ & 1.67 & $\mathrm{P}(5)-\mathrm{O}(6)$ & 1.67 \\
\hline \multirow[t]{3}{*}{$\mathrm{P}(1)-\mathrm{O}(13)$} & 1.57 & $\mathrm{P}(1)-\mathrm{O}(13)$ & 1.57 & $\mathrm{P}(1)-\mathrm{O}(13)$ & 1.57 & $\mathrm{P}(1)-\mathrm{O}(13)$ & 1.57 \\
\hline & & $\mathrm{Fe}(21)-\mathrm{O}(10)$ & 1.82 & $\mathrm{Zn}(16)-\mathrm{O}(10)$ & 1.89 & $\mathrm{Zn}(21)-\mathrm{O}(10)$ & 1.85 \\
\hline & & & & $\mathrm{Ca}(15)-\mathrm{O}(17)$ & 2.17 & & \\
\hline$<\mathrm{O}(10)-\mathrm{Ca}(15)-\mathrm{O}(4)$ & 140.77 & $<\mathrm{O}(10)-\mathrm{Ca}(14)-\mathrm{O}(4)$ & 150.17 & $<\mathrm{O}(10)-\mathrm{Ca}(15)-\mathrm{O}(4)$ & 152.69 & $<\mathrm{O}(10)-\mathrm{Ca}(14)-\mathrm{O}(4)$ & 157.12 \\
\hline$<\mathrm{O}(14)-\mathrm{Ca}(15)-\mathrm{O}(11)$ & 127.08 & $<\mathrm{O}(18)-\mathrm{Ca}(14)-\mathrm{O}(11)$ & 125.17 & $<\mathrm{O}(1)-\mathrm{Ca}(15)-\mathrm{O}(11)$ & 117.70 & $<\mathrm{O}(19)-\mathrm{Ca}(14)-\mathrm{O}(11)$ & 83.24 \\
\hline$<\mathrm{O}(6)-\mathrm{P}(5)-\mathrm{O}(10)$ & 113.38 & $<\mathrm{O}(6)-\mathrm{P}(5)-\mathrm{O}(10)$ & 104.77 & $<\mathrm{O}(6)-\mathrm{P}(5)-\mathrm{O}(10)$ & 110.84 & $<\mathrm{O}(6)-\mathrm{P}(5)-\mathrm{O}(10)$ & 110.54 \\
\hline$<\mathrm{O}(8)-\mathrm{P}(5)-\mathrm{O}(14)$ & 114.98 & $<\mathrm{O}(8)-\mathrm{P}(5)-\mathrm{O}(20)$ & 111.70 & $<\mathrm{O}(8)-\mathrm{P}(5)-\mathrm{O}(14)$ & 115.80 & $<\mathrm{O}(8)-\mathrm{P}(5)-\mathrm{O}(20)$ & 115.64 \\
\hline$<\mathrm{O}(4)-\mathrm{P}(1)-\mathrm{O}(13)$ & 125.90 & $<\mathrm{O}(4)-\mathrm{P}(1)-\mathrm{O}(13)$ & 125.51 & $<\mathrm{O}(4)-\mathrm{P}(1)-\mathrm{O}(13)$ & 126.07 & $<\mathrm{O}(4)-\mathrm{P}(1)-\mathrm{O}(13)$ & 125.22 \\
\hline
\end{tabular}

or $\mathrm{Zn}$ to the oxygen of the phosphate group of TSP could follow. It was observed from the optimized structure that bond distance between $\mathrm{Fe}$ to oxygen of $\mathrm{PO}_{4}$ was shorter, which is $\mathrm{Fe}(21)-\mathrm{O}(10) 1.82 \AA$ than $\mathrm{Zn}(21)-\mathrm{O}(10) 1.85 \AA$. It could be an evidence of the strong interaction between $\mathrm{Fe}$ and $\mathrm{PO}_{4}$.

Remarkable changes were seen in bond angles of TSP when formed complex with $\mathrm{ZnO} .<\mathrm{O}(10)-\mathrm{Ca}(15)-\mathrm{O}(4),<\mathrm{O}(14)-\mathrm{Ca}(15)-\mathrm{O}(11)$, and $<\mathrm{O}(6)-\mathrm{P}(5)-\mathrm{O}(10)$ bond angles of TSP were changed in TSP-ZnO complex. Due to strong interaction between TSP-ZnO complexes, phosphate group of TSP was flipped compared to the position of the $\mathrm{PO}_{4}$ in TSP structure.

Differences of binding energy, enthalpy, and Gibbs free energy are listed in Table 3. For TSP-FeSO energy changes are $-343.941,-346.303$, and $-297.207 \mathrm{KJ} / \mathrm{mol}$. On the other hand, for TSP-ZnO, the levels are $-351.292,-353.655$, and $-307.709 \mathrm{KJ} / \mathrm{mol}$, for $\mathrm{TSP} \mathrm{ZnSO}_{4}$ the levels are $-432.682,-435.308$, and $-377.284 \mathrm{KJ} / \mathrm{mol}$, respectively. Results suggested that the complexes are thermodynamically stable.

Frontier molecular orbitals (MO) i.e., highest occupied molecular orbital (HOMO), lowest unoccupied molecular orbital (LUMO), and their energy gaps are essential factors to measure the chemical reactivity, extent of affinity and kinetic stability of a complex compound [8]. Larger HOMO-LUMO gap of the complexes means high kinetic stability but low chemical reactivity. In that case, an electron requires high energy to be promoted from HOMO to a relatively high-energy level LUMO. The HOMO and LUMO energy gaps of all metal compounds, TSP, and TSP-metal complexes are summarized in Table 4 and Figure 3. 


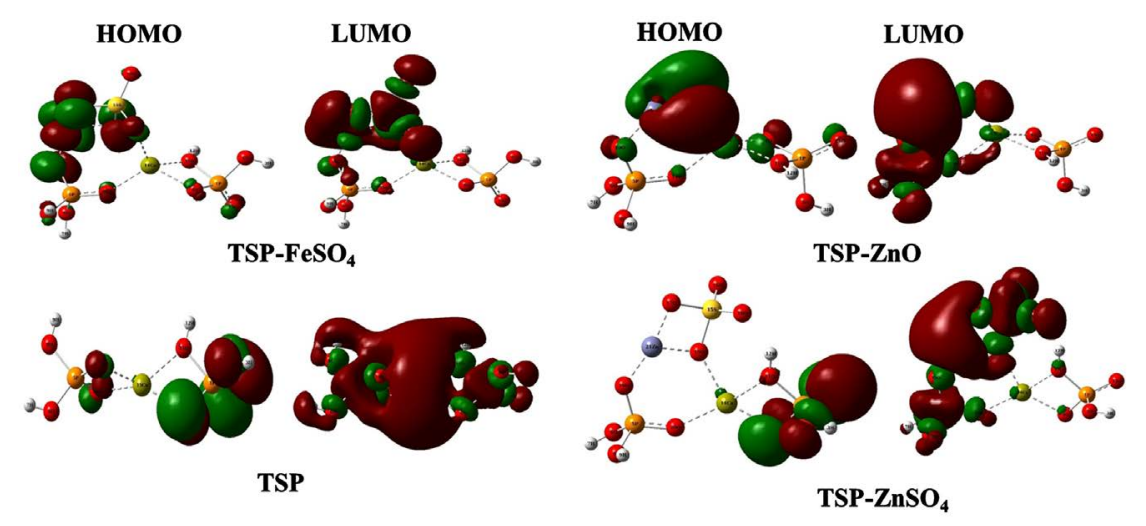

Figure 3. Frontier molecular orbitals (HOMO and LUMO) of TSP and TSP-metal complexes calculated at B3LYP/SDD level of theory.

Table 3. Differences of electronic energies (KJ/mol), enthalpies (KJ/mol), and Gibbs free energies $(\mathrm{KJ} / \mathrm{mol})$ of the TSP-metal complexes and DAP-metal complexes calculated at B3LYP/SDD level of theory.

\begin{tabular}{cccc}
\hline & $\mathrm{TSP}^{-\mathrm{FeSO}_{4}}$ & $\mathrm{TSP}-\mathrm{ZnO}$ & $\mathrm{TSP} \mathrm{ZnSO}{ }_{4}$ \\
\hline$\Delta \mathrm{E}$ & -343.941 & -351.292 & -432.682 \\
$\Delta \mathrm{H}$ & -346.303 & -353.655 & -435.308 \\
$\Delta \mathrm{G}$ & -297.207 & -307.709 & -377.284 \\
$\Delta \mathrm{E}$ & $\mathrm{DAP}^{-\mathrm{FeSO}_{4}}$ & $\mathrm{DAP}-\mathrm{ZnO}$ & ${\mathrm{DAP}-\mathrm{ZnSO}_{4}}$ \\
$\Delta \mathrm{H}$ & -377.809 & -379.122 & -429.532 \\
$\Delta \mathrm{G}$ & -380.172 & -381.485 & -431.950 \\
\hline
\end{tabular}

Table 4. Dipole moments (Debye), energies (eV) of HOMO and LUMO orbitals, HOMO-LUMO gaps (eV), and hardness (eV) and softness (eV) of metal compounds, TSP-metal complexes and DAP-metal complexes are calculated at B3LYP/SDD level of theory.

\begin{tabular}{|c|c|c|c|c|c|c|}
\hline Combinations & $\begin{array}{l}\text { Dipole Moment } \\
\text { (Debye) }\end{array}$ & $\begin{array}{l}\text { HOMO } \\
(\mathrm{eV})\end{array}$ & $\begin{array}{l}\text { LUMO } \\
(\mathrm{eV})\end{array}$ & $\begin{array}{c}\text { HOMO-LUMO } \\
\text { Gap }(\mathrm{eV})\end{array}$ & $\begin{array}{c}\text { Hardness } \\
(\mathrm{eV})\end{array}$ & $\begin{array}{l}\text { Softness } \\
(\mathrm{eV})\end{array}$ \\
\hline $\mathrm{FeSO}_{4}$ & 4.9631 & -8.0148 & -4.6970 & 3.3178 & 1.6595 & 0.6026 \\
\hline $\mathrm{ZnO}$ & 5.0264 & -7.2905 & -4.2994 & 2.9911 & 1.4956 & 0.6686 \\
\hline $\mathrm{ZnSO}_{4}$ & 7.0110 & -8.3397 & -5.6224 & 2.7173 & 1.3587 & 0.7360 \\
\hline TSP & 5.3899 & -8.0676 & -1.9138 & 6.1538 & 3.0769 & 0.3250 \\
\hline TSP-FeSO & 5.5839 & -7.7172 & -3.8969 & 3.8203 & 1.9102 & 0.5235 \\
\hline TSP-ZnO & 9.8717 & -7.1171 & -2.8196 & 4.2975 & 2.1488 & 0.4654 \\
\hline $\mathrm{TSP}-\mathrm{ZnSO}_{4}$ & 12.073 & -7.6456 & -3.4025 & 4.2431 & 2.1216 & 0.4713 \\
\hline DAP & 5.0713 & -7.1400 & -0.4327 & 6.7073 & 3.3537 & 0.2982 \\
\hline $\mathrm{DAP}-\mathrm{FeSO}_{4}$ & 5.1759 & -6.2545 & -2.2202 & 4.0343 & 2.0172 & 0.4957 \\
\hline DAP-ZnO & 8.1366 & -6.7022 & -1.2580 & 5.4442 & 2.7221 & 0.3674 \\
\hline DAP-ZnSO ${ }_{4}$ & 7.3715 & -7.6206 & -2.1766 & 5.4440 & 2.7220 & 0.3673 \\
\hline
\end{tabular}


It was observed that Fe has a noticeable effect on the frontier molecular orbital energies. Compared to the TSP, the HOMO and LUMO energy gaps of the Fe-TSP and Zn-TSP complexes had significantly decreased. Among these, Fe-TSP has the least HOMO-LUMO gap. The HOMO and LUMO energy gap of the TSP, TSP-FeSO, TSP-ZnO, and TSP- $\mathrm{ZnSO}_{4}$ complexes are 6.1538, 3.8203, $4.2975,4.2431(\mathrm{eV})$, respectively, where dipole moments of these complexes are 5.3899, 5.5839, 9.8717, 12.073 (Debye), respectively. Moreover, Fe-TSP complex structure is softer than the Zn-TSP complexes (Table 4). These results confirmed that Fe-TSP complex is more reactive and stable than $\mathrm{Zn}$-TSP complexes.

\subsection{Interaction and Binding of Fe and Zn with DAP}

Equilibrium geometry and the optimized structures of DAP and its complexes DAP-FeSO ${ }_{4}, \mathrm{DAP}-\mathrm{ZnO}$, and $\mathrm{DAP}-\mathrm{ZnSO}_{4}$ are depicted in Figure 4. Selected bond distances and angles of the complexes are summarized in Table 5 (atom numbers are shown in the optimized structures). In the structure of DAP-ZnO, few significant changes were occurred compared to the structure of DAP. $\mathrm{O}(5)-\mathrm{H}(7)$ and $\mathrm{O}(2)-\mathrm{H}(12)$ bonds got elongated from $1.07 \AA$ to $1.39 \AA$ and 1.09 $\AA$ to $2.03 \AA$. Zn oxide showed strong affinity to the $\mathrm{PO}_{4}$ of DAP since bond distance between $\mathrm{Zn}$ and $\mathrm{O}$ of the phosphate group of DAP $(\mathrm{Zn}(17)-\mathrm{O}(3))$ is only $1.85 \AA$. Due to the strong attraction, $\mathrm{P}(1)-\mathrm{O}(3)$ bond of $\mathrm{PO}_{4}$ of $\mathrm{DAP}-\mathrm{Zn}$ had changed significantly. Besides this, the bond distance of $\mathrm{Fe}(22)-\mathrm{O}(2) 1.95 \AA$ in DAP-FeSO ${ }_{4}$ is shorter than $\mathrm{Zn}(17)-\mathrm{O}(2) 1.97 \AA$ in $\mathrm{DAP}^{-} \mathrm{ZnSO}_{4}$. This result implies that the affinity of $\mathrm{Fe}$ and phosphate group of the fertilizers are stronger than Zn-phosphate interaction. Therefore, $\mathrm{P}(1)-\mathrm{O}(3)$ of $\mathrm{DAP}_{-} \mathrm{FeSO}_{4}$ got elongated from $1.59 \AA 1.66 \AA$ (Table 5).

Table 5. Selected bond distances $(\AA)$ and angles $\left({ }^{\circ}\right)$ of DAP-metal complexes calculated at B3LYP/SDD level of theory.

\begin{tabular}{ccccccccc}
\hline Assignment & DAP & Assignment & DAP-FeSO & Assignment & DAP-ZnO & Assignment & DAP-ZnSO $_{4}$ \\
\hline $\mathrm{N}(8)-\mathrm{H}(7)$ & 1.53 & $\mathrm{~N}(8)-\mathrm{H}(7)$ & 1.10 & $\mathrm{~N}(8)-\mathrm{H}(7)$ & 1.39 & $\mathrm{~N}(8)-\mathrm{H}(7)$ & 1.09 \\
$\mathrm{~N}(13)-\mathrm{H}(7)$ & 1.47 & $\mathrm{~N}(13)-\mathrm{H}(7)$ & 1.10 & $\mathrm{~N}(13)-\mathrm{H}(14)$ & 1.79 & $\mathrm{~N}(13)-\mathrm{H}(7)$ & 1.05 & 1.51 \\
$\mathrm{O}(5)-\mathrm{H}(7)$ & 1.07 & $\mathrm{O}(5)-\mathrm{H}(7)$ & 1.51 & $\mathrm{O}(5)-\mathrm{H}(7)$ & 1.39 & $\mathrm{O}(5)-\mathrm{H}(7)$ & $\mathrm{O}(2)-\mathrm{H}(12)$ & 1.80 \\
$\mathrm{O}(2)-\mathrm{H}(12)$ & 1.09 & $\mathrm{O}(2)-\mathrm{H}(12)$ & 1.48 & $\mathrm{O}(2)-\mathrm{H}(12)$ & 2.03 & $\mathrm{P}(1)-\mathrm{O}(5)$ & 1.67 \\
$\mathrm{P}(1)-\mathrm{O}(5)$ & 1.68 & $\mathrm{P}(1)-\mathrm{O}(5)$ & 1.60 & $\mathrm{P}(1)-\mathrm{O}(5)$ & 1.63 & $\mathrm{P}(1)-\mathrm{O}(2)$ & 1.69 \\
$\mathrm{P}(1)-\mathrm{O}(2)$ & 1.65 & $\mathrm{P}(1)-\mathrm{O}(2)$ & 1.70 & $\mathrm{P}(1)-\mathrm{O}(2)$ & 1.60 & $\mathrm{P}(1)-\mathrm{O}(3)$ & 1.57 \\
$\mathrm{P}(1)-\mathrm{O}(3)$ & 1.59 & $\mathrm{P}(1)-\mathrm{O}(3)$ & 1.66 & $\mathrm{P}(1)-\mathrm{O}(3)$ & 1.67 & $\mathrm{Zn}(17)-\mathrm{O}(2)$ & 1.97 \\
& & $\mathrm{Fe}(22)-\mathrm{O}(3)$ & 1.97 & $\mathrm{Zn}(17)-\mathrm{O}(3)$ & 1.85 & $\mathrm{Zn}$ & $\mathrm{Zn}(17)-\mathrm{O}(21)$ & 1.95 \\
& & $\mathrm{Fe}(22)-\mathrm{O}(2)$ & 1.95 & $\mathrm{Zn}(17)-\mathrm{O}(18)$ & 1.77 & $\mathrm{O}(5)-\mathrm{P}(1)-\mathrm{O}(3)$ & 121.09 \\
$\mathrm{O}(5)-\mathrm{P}(1)-\mathrm{O}(3)$ & 112.98 & $\mathrm{O}(5)-\mathrm{P}(1)-\mathrm{O}(3)$ & 117.35 & $\mathrm{O}(5)-\mathrm{P}(1)-\mathrm{O}(3)$ & 111.83 & $\mathrm{O}(1)$ \\
$\mathrm{O}(5)-\mathrm{P}(1)-\mathrm{O}(2)$ & 103.86 & $\mathrm{O}(5)-\mathrm{P}(1)-\mathrm{O}(2)$ & 114.51 & $\mathrm{O}(5)-\mathrm{P}(1)-\mathrm{O}(2)$ & 119.42 & $\mathrm{O}(5)-\mathrm{P}(1)-\mathrm{O}(2)$ & 95.63 \\
$\mathrm{O}(3)-\mathrm{P}(1)-\mathrm{O}(2)$ & 118.38 & $\mathrm{O}(3)-\mathrm{P}(1)-\mathrm{O}(2)$ & 93.71 & $\mathrm{O}(3)-\mathrm{P}(1)-\mathrm{O}(2)$ & 106.53 & $\mathrm{O}(3)-\mathrm{P}(1)-\mathrm{O}(2)$ & 123.38 \\
\hline
\end{tabular}




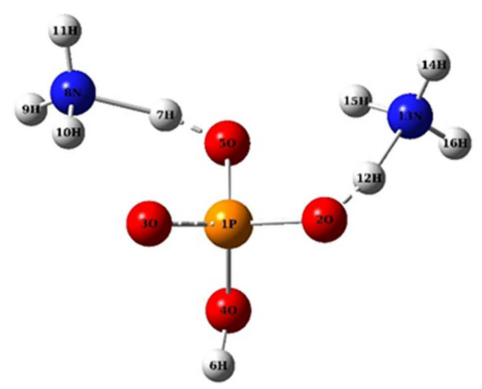

(a)

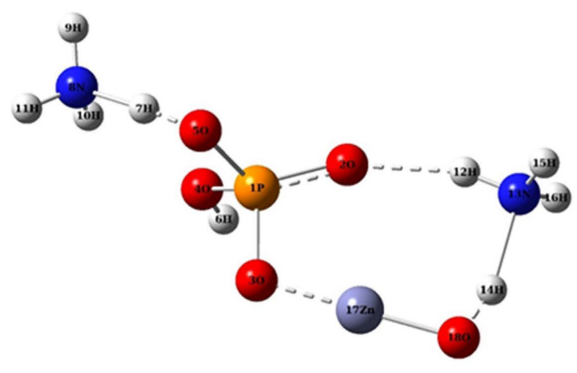

(c)

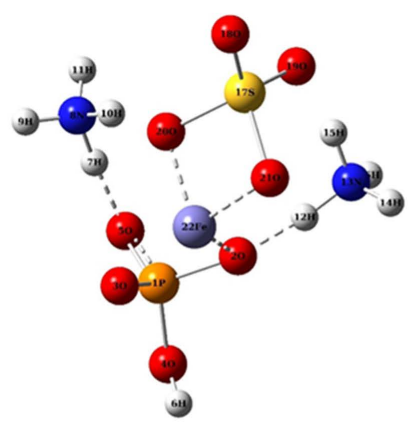

(b)

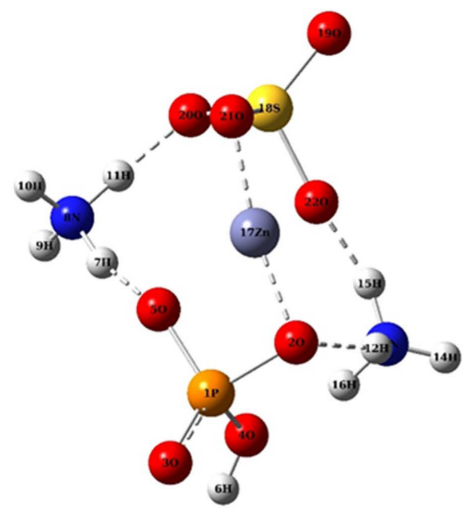

(d)

Figure 4. Optimized structures of (a) DAP; (b) DAP-FeSO4; (c) DAP-ZnO; and (d) DAP-ZnSO4 computed at B3LYP/SDD level of theory.

Moreover, remarkable changes were seen in bond angles. Specially, $<\mathrm{O}(5)-\mathrm{P}(1)-\mathrm{O}(2),<\mathrm{O}(3)-\mathrm{P}(1)-\mathrm{O}(2)$ bond angles of $\mathrm{PO}_{4}$ in DAP were $103.86^{\circ}$ and $118.38^{\circ}$, which had changed significantly by the strong interaction of $\mathrm{Fe}$ and $\mathrm{Zn}$ compounds (Table 5 and Figure 4). So, both Fe and $\mathrm{Zn}$ metals have a strong affinity to the oxygen of $\mathrm{PO}_{4}$ group. HOMO-LUMO gap, dipole moment change, and hardness and softness of the complexes (Table 4) could help to understand the interactions more comprehensively.

Electronic energy, enthalpy, and Gibbs free energy of metal-fertilizer complexes are summarized in Table 3. As predicted, the difference of electronic energy, enthalpy, and Gibbs free energy of DAP- $\mathrm{FeSO}_{4}$ are $-377.809,-380.172$, and $-321.099 \mathrm{KJ} / \mathrm{mol}$. On the other hand, for DAP-ZnO, the levels are $-379.122,-381.485$, and $-342.890 \mathrm{KJ} / \mathrm{mol}$; for $\mathrm{DAP}-\mathrm{ZnSO}_{4}$, the levels are $-429.532,-431.950$, and $-367.045 \mathrm{KJ} / \mathrm{mol}$, respectively. This suggests that the complexes are thermodynamically stable. Moreover, binding energies also recommend that the affinity of between Fe and $\mathrm{Zn}$ compounds toward DAP is strong. The HOMO and LUMO energies of all DAP and DAP-metal complexes are summarized in Table 4 and Figure 5. It was observed that Fe has a significant effect on the frontier molecular orbital energies. Compared to DAP, the HOMO and LUMO energy gaps of the Fe-DAP and Zn-DAP complexes are significantly decreased where the HOMO-LUMO gap of Fe-DAP was least. The HOMO and LUMO energy gap of the DAP, DAP-FeSO ${ }_{4}, \mathrm{DAP}-\mathrm{ZnO}$, and 


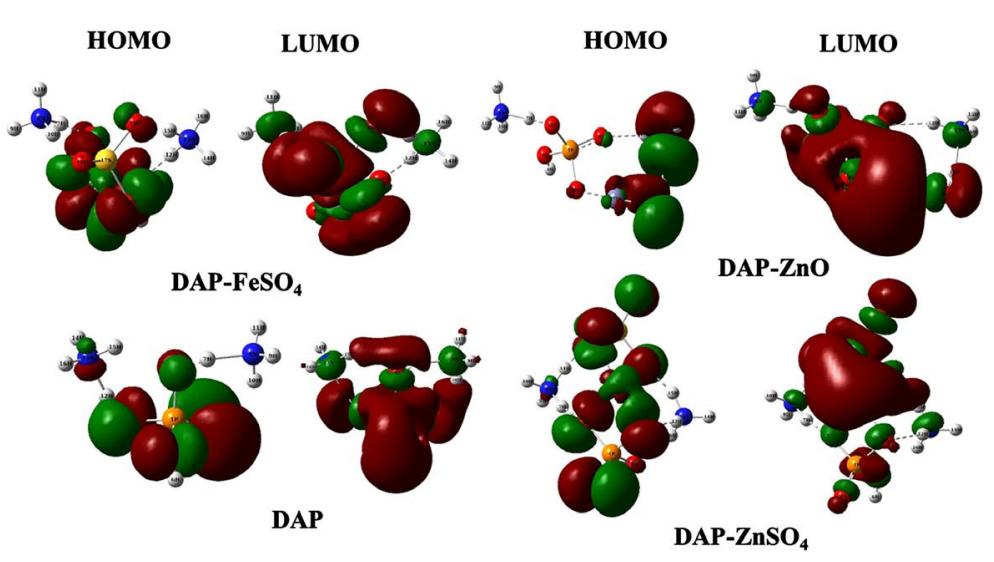

Figure 5. Frontier molecular orbitals (HOMO and LUMO) of DAP and DAP-metal complexes calculated at B3LYP/SDD level of theory.

DAP- $\mathrm{ZnSO}_{4}$ complexes are 6.7073, 4.0343, 5.4442, and $5.4440 \mathrm{eV}$, respectively. The results suggest that Fe-complex is chemically more reactive to DAP than Zn-complexes. Dipole moments of these complexes are 5.0713, 5.1759, 8.1366, and 7.3715 Debye, respectively. Trend of the dipole moment is also proving the earlier assumption. Moreover, Fe-DAP complex structure is softer than the Zn-DAP complexes (Table 4).

Therefore, quantum mechanical calculation confirmed that both Fe-DAP/TSP and Zn-DAP/TSP complexes are thermodynamically stable, which supports experimental results. It was also observed that Fe-DAP/TSP complexes are more reactive and stable than $\mathrm{Zn}$-DAP/TSP complexes because Fe-DAP complex has lower HOMO-LUMO gap and Fe- $\mathrm{PO}_{4}$ bond distance is smaller than the $\mathrm{Zn}-\mathrm{PO}_{4}$.

\section{Conclusion}

Concentrations of essential metals, Fe and $\mathrm{Zn}$, in some of the fertilizer samples were found to be surprisingly high. Density functional theory revealed that $\mathrm{Fe}$ and $\mathrm{Zn}$ have strong affinity with the $\mathrm{PO}_{4}$ group present in DAP and TSP. It was proved because both $\mathrm{Fe}$ and $\mathrm{Zn}$ with the oxygen of the $\mathrm{PO}_{4}$ group formed covalent like bonding, and the complexes were found thermodynamically stable. HOMO-LUMO gap indicated that Fe compound was more prone to attach with the $\mathrm{PO}_{4}$ group of the fertilizers due to lower HOMO-LUMO gap than $\mathrm{Zn}$-fertilizer complexes. Therefore, the combined experimental and theoretical studies revealed that excess Fe and $\mathrm{Zn}$ could be stayed with fertilizers in the soil over a long period, gradually be bioaccumulated by the application of either excess phosphate fertilizers or excess metal ingested fertilizers, and eventually could go into food web.

\section{Acknowledgements}

The authors are grateful to the Director, INST and Head, Reactor and Neutron Physics Division, INST, AERE, Bangladesh for their permission to use the NAA laboratory facilities. Besides, all authors are also grateful to Dr. Mohammad A. 
Halim, CEO of the Red-Green Research Centre (RGRC) for giving permission to use the computational chemistry lab facilities of RGRC

(http://grc-bd.org/donate/).

\section{Conflicts of Interest}

The authors declare no conflicts of interest regarding the publication of this paper.

\section{References}

[1] Food and Agriculture Organization of United Nations (2015) World Fertilizer Trends and Outlook to 2018.

[2] Khabarov, N. and Obersteiner, M. (2017) Global Phosphorus Fertilizer Market and National Policies: A Case Study Revisiting the 2008 Price Peak. Frontiers in Nutrition, 4, 22. https://doi.org/10.3389/fnut.2017.00022

[3] HELM AG (2019) Triple Super Phosphate. HELM AG Website. https://www.helmag.com/products/product-details/product/triple-super-phospha te/

[4] Westfall, D.G., Mortvedt, J.J., Peterson, G.A. and Gangloff, W.J. (2005) Efficient and Environmentally Safe Use of Micronutrients in Agriculture. Communications in Soil Science and Plant Analysis, 36, 169-182. https://doi.org/10.1081/CSS-200043024

[5] Righi, S., Lucialli, P., and Bruzzi, L. (2005) Health and Environmental Impacts of a Fertilizer Plant-Part I: Assessment of Radioactive Pollution. Journal of Environmental Radioactivity, 82, 167-182. https://doi.org/10.1016/j.jenvrad.2004.11.007

[6] Bandyopadhyay, S., Ghosh, K. and Varadachari, C. (2014) Multimicronutrient Slow-Release Fertilizer of Zinc, Iron, Manganese, and Copper. International Journal of Chemical Engineering, 2014, Article ID: 327153.

https://doi.org/10.1155/2014/327153

[7] Plant and Soil Sciences eLibrary (2019) Common Forms of Those Metals in the Fertilizers. USDA/NIFA. http://passel.unl.edu/pages/

[8] Rahman, M.S., Hossain, S.M., Rahman, M.T., Halim, M.A., Ishtiak, M.N. and Kabir, M. (2017) Determination of Trace Metal Concentration in Compost, DAP, and TSP Fertilizers by Neutron Activation Analysis (NAA) and Insights from Density Functional Theory Calculations. Environmental Monitoring and Assessment, 189, 618. https://doi.org/10.1007/s10661-017-6328-1

[9] McLaughlin, M.J., Tiller, K.G., Naidu, R. and Stevens, D.P. (1996) Review: The Behaviour and Environmental Impact of Contaminants in Fertilizers. Australian Journal of Soil Research, 34, 1-54. https://doi.org/10.1071/SR9960001

[10] Ruddy, B.C., Lorenz, D.L. and Mueller, D.K. (2006) County-Level Estimates of Nutrient Inputs to the Land Surface of the Conterminous United States, 1982-2001. USGS Scientific Investigations Report 2006-5012. https://doi.org/10.3133/sir20065012

[11] Jasinski, S.M. (1999) Fertilizers: Sustaining Global Food Supplies. U.S. Geological Survey Fact Sheet 155-99. https://doi.org/10.3133/fs15599

[12] USDA (2018) Fertilizer Use and Price Datasets. U.S. Department of Agriculture Economic Research Service. 
https://www.ers.usda.gov/data-products/fertilizer-use-and-price.aspx

[13] Audebert, A. and Sahrawat, K.L. (2000) Mechanisms for Iron Toxicity Tolerance in Lowland Rice. Journal of Plant Nutrition, 23, 1877-1885.

https://doi.org/10.1080/01904160009382150

[14] Sarwar, N., et al. (2015) Zinc-Cadmium Interactions: Impact on Wheat Physiology and Mineral Acquisition. Ecotoxicology and Environmental Safety, 122, 528-536. https://doi.org/10.1016/j.ecoenv.2015.09.011

[15] Liu, Y., Baas, J., Peijnenburg, W.J.G.M. and Vijver, M.G. (2016) Evaluating the Combined Toxicity of $\mathrm{Cu}$ and $\mathrm{ZnO}$ Nanoparticles: Utility of the Concept of Additivity and a Nested Experimental Design. Environmental Science \& Technology, 50, 5328-5337. https://doi.org/10.1021/acs.est.6b00614

[16] Chaney, R.L. (1993) Zinc Phytotoxicity. In: Robson, A.D., Ed., Zinc in Soils and Plants. Developments in Plant and Soil Sciences, Springer, Dordrecht, 135-150. https://doi.org/10.1007/978-94-011-0878-2_10

[17] Rim, K.T., Koo, K.H. and Park, J.S. (2013) Toxicological Evaluations of Rare Earths and Their Health Impacts to Workers: A Literature Review. Safety and Health at Work, 4, 12-26. https://doi.org/10.5491/SHAW.2013.4.1.12

[18] Popescu, I.V., et al. (2009) Environmental Samples Analysis by Atomic Absorption Spectrometry (AAS) and Inductively Coupled Plasma-Optical Emission Spectroscopy. Romanian Journal of Physics, 54, 741-746.

[19] Daud, M., Wasim, M., Khalid, N., Zaidi, J.H. and Iqbal, J. (2009) Assessment of Elemental Pollution in Soil of Islamabad City Using Instrumental Neutron Activation Analysis and Atomic Absorption Spectrometry Techniques. Radiochimica Acta, 97, 117-122. https://doi.org/10.1524/ract.2009.1578

[20] Radulescu, C., Stihi, C., Busuioc, G., Popescu, I.V., Gheboianu, A.I. and Cimpoca, V.G. (2010) Evaluation of Essential Elements and Heavy Metal Levels in Fruiting Bodies of Wild Mushrooms and Their Substrate by EDXRF Spectrometry and FAA Spectrometry. Romanian Biotechnological Letters, 15, 5444-5456.

[21] Simms, P.A.F.R. (2002) The Multielemental Analysis of Drinking Water Using Proton-Induced X-Ray Emission (Pixe). U.S. Environmental Protection Agency, Washington DC.

[22] IAEA (2001) Use of Research Reactors for Neutron Activation Analysis. Advisory Group Meeting, Vienna, 22-26 June 1998, 22-26.

[23] Becke, A.D. (2014) Perspective: Fifty Years of Density-Functional Theory in Chemical Physics. The Journal of Chemical Physics, 140, Article ID: 18A30. https://doi.org/10.1063/1.4869598

[24] Frisch, M.J., et al. (2009) Gaussian 09 Revision A.1. Gaussian 09, Revision A.02. https://gaussian.com/g09citation/

[25] Lee, C., Yang, W. and Parr, R.G. (1988) Development of the Colle-Salvetti Correlation-Energy Formula into a Functional of the Electron Density. Physical Review $B$, 37, 785-789. https://doi.org/10.1103/PhysRevB.37.785

[26] Andrae, D., Häußermann, U., Dolg, M., Stoll, H. and Preuß, H. (1990) Energy-Adjustedab initio Pseudopotentials for the Second and Third Row Transition Elements. Theoretica Chimica Acta, 77, 123-141. https://doi.org/10.1007/BF01114537

[27] Nziguheba, G. and Smolders, E. (2008) Inputs of Trace Elements in Agricultural Soils via Phosphate Fertilizers in European Countries. Science of the Total Environment, 390, 53-57. https://doi.org/10.1016/j.scitotenv.2007.09.031 
[28] Abdel-Haleem, A.S., Sroor, A., El-Bahi, S.M. and Zohny, E. (2001) Heavy Metals and Rare Earth Elements in Phosphate Fertilizer Components Using Instrumental Neutron Activation Analysis. Applied Radiation and Isotopes, 55, 569-573. https://doi.org/10.1016/S0969-8043(01)00098-7

[29] Molina, M., Aburto, F., Calderón, R., Cazanga, M. and Escudey, M. (2009) Trace Element Composition of Selected Fertilizers Used in Chile: Phosphorus Fertilizers as a Source of Long-Term Soil Contamination. Soil and Sediment Contamination: An International Journal, 18, 497-511. https://doi.org/10.1080/15320380902962320

[30] Chahal, V., Chand, P., Nagpal, A., Katnoria, J.K. and Pakade, Y.B. (2014) Evaluation of Heavy Metals Contamination and Its Genotoxicity in Agricultural Soil of Amritsar, Punjab, India. International Journal of Research in Chemistry and Environment, 75, 786.

[31] Kabata-Pendias, A. (2000) Trace Elements in Soils and Plants. 3rd Edition, CRC Press, Boca Raton, FL. https://doi.org/10.1201/9781420039900

[32] Angelone, M. and Bini, C. (1992) Trace Element Concentrations in Soils and Plants of Western Europe. In: Adriano, D.C., Ed., Biogeochemistry of Trace Metals, CRC Press, Boca Raton, FL, 19-60. https://doi.org/10.1201/9781315150260

[33] Eriksson, J. (2001) Concentrations of 61 Trace Elements in Sewage Sludge, Farmyard Manure, Mineral Fertiliser, Precipitation and in Oil and Crops. Swedish Environmental Protection Agency.

[34] Holmgren, G.G.S., Meyer, M.W., Chaney, R.L. and Daniels, R.B. (2010) Cadmium, Lead, Zinc, Copper, and Nickel in Agricultural Soils of the United States of America. Journal of Environmental Quality, 22, 335-348. https://doi.org/10.2134/jeq1993.00472425002200020015x

[35] Takeda, A., Kimura, K. and Yamasaki, S.I. (2004) Analysis of 57 Elements in Japanese Soils, with Special Reference to Soil Group and Agricultural Use. Geoderma, 119, 291-307.

[36] Turra, C., Fernandes, E.A.N., Bacchi, M.A., De Energia, C. and Paulo, U.D.S. (2011) Evaluation on Rare Earth Elements of Brazilian Agricultural Supplies. Journal of Environmental Chemistry and Ecotoxicology, 3, 86-92.

[37] Laul, J.C., Weimer, W.C. and Rancitelli, L.A. (1979) Biogeochemical Distribution of Rare Earths and Other Trace Elements in Plants and Soils. Physics and Chemistry of the Earth, 11, 819-827. https://doi.org/10.1016/0079-1946(79)90076-4

[38] Ramos, S.J., et al. (2016) Rare Earth Elements in the Soil Environment. Current Pollution Reports, 2, 28-50. https://doi.org/10.1007/s40726-016-0026-4

[39] Diatloff, E., Asher, C.J. and Smith, F.W. (1996) Concentrations of Rare Earth Elements in Some Australian Soils. Australian Journal of Soil Research, 34, 735-747. https://doi.org/10.1071/SR9960735

[40] Salminen, R., et al. (2005) Geochemical Atlas of Europe. Part 1: Background Information, Methodology and Maps. Geological Survey of Finland. Espoo.

[41] Waheed, S., Javied, S., Siddique, N., Shakoor, R. and Tufail, M. (2011) Rare Earths Elements in Phosphorite and Granulated Single Super-Phosphate Fertilizers of Pakistan, a Study Using Instrumental Neutron Activation Analysis. Journal of Radioanalytical and Nuclear Chemistry, 289, 521-528. https://doi.org/10.1007/s10967-011-1112-0

[42] Guilherme, C., et al. (2014) Elementos terras raras em solos agrícolas com aplicações de fertilizante fosfatado e fosfogesso. Ciência do Solo, 1, 100. 


\section{Supporting Information}

Table S1. Coordination data of the sample collection area of the mid-southern part of Bangladesh.

\begin{tabular}{ccc}
\hline Locations of the Study & \multicolumn{2}{c}{ Coordination } \\
\hline Agargaon & $23^{\circ} 46^{\prime} 45.1^{\prime \prime} \mathrm{N}$ & $90^{\circ} 22^{\prime} 25.17^{\prime \prime} \mathrm{E}$ \\
Mirpur-2 & $23^{\circ} 48^{\prime} 17^{\prime \prime} \mathrm{N}$ & $90^{\circ} 21^{\prime} 48^{\prime \prime} \mathrm{E}$ \\
Savar & $23^{\circ} 51^{\prime} 29.88^{\prime \prime} \mathrm{N}$ & $90^{\circ} 16^{\prime} 0.12^{\prime \prime} \mathrm{E}$ \\
Alfadanga & $23^{\circ} 17^{\prime} 0^{\prime \prime} \mathrm{N}$ & $89^{\circ} 43^{\prime} 00^{\prime \mathrm{E}}$ \\
Mohammadpur (Magura) & $23^{\circ} 24^{\prime} 18^{\prime \prime} \mathrm{N}$ & $89^{\circ} 36^{\prime} 18^{\prime \prime} \mathrm{E}$ \\
Saltha & $23^{\circ} 24^{\prime} 21.8^{\prime \prime} \mathrm{N}$ & $89^{\circ} 47^{\prime} 39.4^{\prime \prime} \mathrm{E}$ \\
Agargaon & $23^{\circ} 46^{\prime} 45.1^{\prime \prime} \mathrm{N}$ & $90^{\circ} 22^{\prime} 25.17^{\prime \prime} \mathrm{E}$ \\
Mirpur-2 & $23^{\circ} 48^{\prime} 17^{\prime \prime} \mathrm{N}$ & $90^{\circ} 21^{\prime} 48^{\prime \prime} \mathrm{E}$ \\
\hline
\end{tabular}

Table S2. Detection limits of the studied metals.

\begin{tabular}{cc}
\hline Elements & Detection Limit $(\mathrm{mg} / \mathrm{kg})$ \\
\hline $\mathrm{Fe}$ & 410.00 \\
$\mathrm{Sc}$ & 0.079 \\
$\mathrm{Sm}$ & 0.024 \\
$\mathrm{Zn}$ & 28.49 \\
\hline
\end{tabular}

Table S3. Ranges and mean concentrations of Fe (mg/kg), Zn (mg/kg), Sc (mg/kg), and $\mathrm{Sm}(\mathrm{mg} / \mathrm{kg})$ in the soil of different countries.

\begin{tabular}{cccccc}
\hline $\begin{array}{c}\text { Region/ } \\
\text { Country }\end{array}$ & $\begin{array}{c}\text { Ranges } \\
\text { Sc }(\mathrm{mg} / \mathrm{kg})\end{array}$ & $\begin{array}{c}\text { Mean } \\
\mathrm{Sc}(\mathrm{mg} / \mathrm{kg})\end{array}$ & $\begin{array}{c}\text { Ranges } \\
\text { Sm }(\mathrm{mg} / \mathrm{kg})\end{array}$ & $\begin{array}{c}\text { Mean } \\
\text { Sm }(\mathrm{mg} / \mathrm{kg})\end{array}$ & References \\
\hline USA & $2.8-17$ & 9.9 & $5.2-6.6$ & 5.9 & {$[37]$} \\
Germany & $0.8-15$ & 6.1 & $0.5-8.7$ & 3.8 & {$[38]$} \\
Australia & - & - & $0.4-4.6$ & 2.8 & {$[39]$} \\
China & $11-13$ & 12 & $1.2-7.8$ & 5.2 & \\
Japan & $0.4-56$ & 17 & $0.2-30$ & 3.8 & {$[38]$} \\
Brazil & $6.6-30$ & 18 & $0.4-6.7$ & 3.5 & \\
Albania & $10-15$ & 13 & $3.6-5.3$ & 4.5 & \\
Austria & $1.3-21$ & 12 & $0.7-10$ & 5.2 & {$[40]$} \\
France & $0.3-29$ & 9.3 & $0.4-11$ & 5.1 & \\
& Ranges & Mean & Ranges & Mean & \\
& Fe (mg/kg) & Fe (mg/kg) & Zn (mg/kg) & Zn (mg/kg) & \\
India (Punjab) & $2800.0-5700.0$ & & $73.0-320.0$ & - & {$[30]$} \\
USA & - & - & $<3-264$ & 43 & {$[34]$} \\
Sweden & - & - & $6-152$ & 65 & {$[33]$} \\
Japan & - & - & $2.5-330$ & 89 & {$[35]$} \\
Europe & - & - & $7-89$ & - & {$[32]$} \\
\hline
\end{tabular}




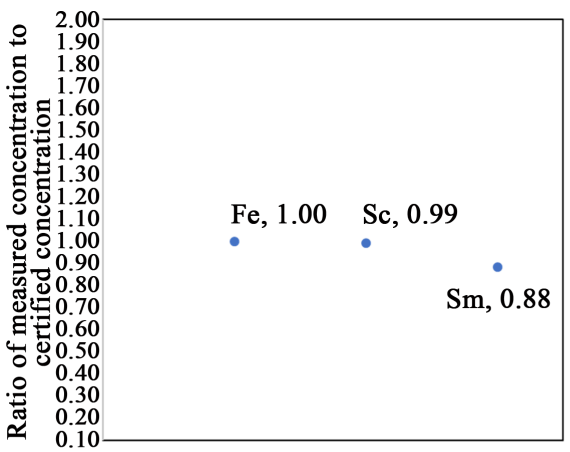

Elements

(a)

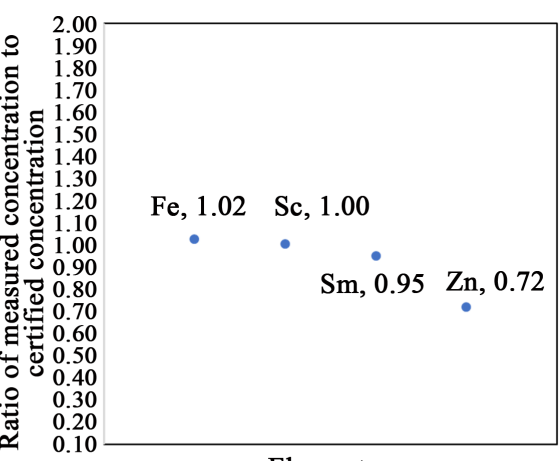

Elements

Figure S1. (a) and (b) quality control graph of the ratio of measured concentration to certified concentration of different elements by IAEA-SL-1 and CRM NIST-1633b Coal Fly Ash, respectively. 